\title{
A training package for zone III Resuscitative Endovascular Balloon Occlusion of the Aorta (REBOA)
}

\author{
Robbie A Lendrum ${ }^{1 *}$, Zane B Perkins ${ }^{1,2}$, Gareth E Davies ${ }^{1}$ \\ From London Trauma Conference 2013 \\ London, UK. 10-13 December 2013
}

\section{Background}

Non-compressible haemorrhage is the leading cause of preventable trauma death, with pelvic and groin haemorrhage associated with mortality rates approaching $50 \%[1,2]$. Trauma systems expedite access to haemorrhage control, however, the majority of patients who die, exsanguinate before control can be achieved. REBOA is an innovative technique that provides the opportunity for meaningful improvements in the outcome of these patients. It involves the positioning of a balloon at the aortic bifurcation (Zone III) as a means of temporary in-flow control and afterload augmentation in patients with severe distal haemorrhage [3]. Our aim is to describe the training package developed to introduce zone III REBOA at a UK Major Trauma Centre.

\section{Methods}

A multidisciplinary working group, consisting of consultants in Pre-Hospital Care, Emergency Medicine, Interventional Radiology, Anaesthesia and Trauma and Vascular Surgery, reviewed the existing REBOA literature and developed a training package that enables procedural knowledge and competence in potential operators.

\section{Results}

The REBOA training package components are:

\section{1) Required reading}

Consists of six publications that detail the background, benefits, technical considerations and worldwide experience with the procedure.

* Correspondence: rlendrum@nhs.net

'London's Air Ambulance, The Royal London Hospital, London, UK

Full list of author information is available at the end of the article

\section{2) Standard operating procedure (SOP)}

An evidence-based SOP defines the target population, equipment, procedure and post-procedure management.

\section{3) Written assessment}

A written assessment, based on the required reading and SOP, tests trainees' knowledge and understanding of the procedure.

\section{4) Equipment familiarisation}

A purpose built mannequin and complete set of training equipment allow trainees to gain technical familiarity with procedural steps and kit.

\section{5) Moulage}

Scripted scenarios are used in multidisciplinary, high fidelity, training "moulages" to test the trainees' leadership, decision-making, teamwork and procedural competence.

\section{6) "Sign-off"}

Potential operators are required to successfully complete all components of the training package under the supervision of a "signed-off" operator.

\section{Conclusion}

REBOA is less invasive and more effective at temporarily controlling exsanguinating pelvic haemorrhage than thoracotomy with aortic compression. As with resuscitative thoracotomy, many clinicians faced with a patient who would benefit from the procedure, will have no prior experience with REBOA. Our training package attempts to address this. 


\section{Authors' details}

'London's Air Ambulance, The Royal London Hospital, London, UK. ${ }^{2}$ Centre for Trauma Sciences, Queen Mary, University of London, UK.

Published: 7 July 2014

\section{References}

1. Perkins ZB, De'Ath HD, Aylwin C, Brohi K, Walsh M, Tai NRM: Epidemiology and outcome of vascular trauma at a British Major Trauma Centre. Eur J Vasc Endovasc Surg 2012, 44:203-9.

2. Perkins Z, Maytham G, Koers L, Bates P, Brohi K, Tai N: A targeted performance improvement programme reduces mortality in exsanguinating pelvic trauma. Scand J Trauma Resusc Emerg Med 2013, 21: S28.

3. Stannard A, Eliason JL, Rasmussen TE: Resuscitative endovascular balloon occlusion of the aorta (REBOA) as an adjunct for hemorrhagic shock. The Journal of Trauma: Injury, Infection, and Critical Care 2011, 71:1869-72.

doi:10.1186/1757-7241-22-S1-P18

Cite this article as: Lendrum et al: A training package for zone III

Resuscitative Endovascular Balloon Occlusion of the Aorta (REBOA).

Scandinavian Journal of Trauma, Resuscitation and Emergency Medicine 2014 22(Suppl 1):P18.

\section{Submit your next manuscript to BioMed Central} and take full advantage of:

- Convenient online submission

- Thorough peer review

- No space constraints or color figure charges

- Immediate publication on acceptance

- Inclusion in PubMed, CAS, Scopus and Google Scholar

- Research which is freely available for redistribution

Submit your manuscript at www.biomedcentral.com/submit 